\title{
Decomposition Analysis for Impact of Backward Integration on Input Use Pattern and Profitability of Chilli Farmers in Andhra Pradesh
}

\author{
Asha R.*, Umadevi K. and Suseela. K \\ Department of Agricultural Economics, Acharya N G Ranga Agricultural University, Agriculture College, Bapatla, Guntur, Andhra \\ Pradesh, India
}

*Corresponding author: asha.rallapalli06@gmail.com (ORCID ID: 0000-0002-1613-2222)

Received: $10-01-2020$

Revised: $15-04-2020$

Accepted: 20-05-2020

\begin{abstract}
The present study find out the was impact of backward integration on chilli farmers in terms of input use pattern and profitability in Andhra Pradesh. Multistage random sampling was selected adopted for the sample selection. A total of 128 sample were taken. Two major Agribusiness firms, i.e., ITC and Synthite that are following backward integration in chilli farming in Prakasam district were purposively selected for the study. The decomposition analysis showed that the per hectare returns of integrated farming was 13.28 per cent higher than that of non-integrated farming. The integrated technology component was contributing 3.7 per cent to the total increase in output. The total contribution of changes in the levels of input use to the outcome differences between the two groups was 9.58 per cent.

\section{Highlights}

(- Decomposition analysis was used to analyse the impact of backward integration on input use pattern and profitability of chilli farmers, the farmers who are following backward integration are getting higher income than farmers who are not following backward integration.
\end{abstract}

\section{Keywords: Backward integration, Chilli, Andhra Pradesh, Decomposition analysis}

Backward integration is a strategy where a firm gains control over ownership or increased control over its suppliers. It basically comprises of four components, pre-agreed price, quality, quantity and time. It was an approach that can bring income for farmers and profitability for companies (Sharma et al. 2014). The potential for increasing exports of whole chillies, crushed chillies and chilli powder in consumer packs is very high, provided the stringent quality requirements of importing countries are met. The consumers in the importing countries insist on 'clean spices' and to meet this challenge, efforts are to be made to prevent contamination from external sources during application of plant protection chemicals, harvesting, post-harvest handling, processing and storage. It is vitally important to support the chilli farmers to produce high quality sustainable food safe spices to compete in the international market. This can be achieved by an integrated approach with the collective efforts of farmers, processors and traders. The agribusiness firms which are mainly engaged with chilli processing are providing extension services to chilli farmers regarding integrated technologies to improve the quality of produce. The major players like ITC and C, Synthite viz., are providing customised solutions to diverse challenges of chilli farmers through backward integration by providing

\footnotetext{
How to cite this article: Asha, R. and Umadevi, K. (2020). Decomposition analysis for impact of backward integration on input use pattern and profitability of chilli farmers in Andhra Pradesh. Economic Affairs, 65(2): 173-178.

Source of Support: None; Conflict of Interest: None 
integrated pest management practices, transport facilities, packing materials and storage facilities. In addition to all these facilities, these agribusiness firms providesing technology transfer through extension services. Gawaria et al. (2010) studied decomposition analysis of output change under new wheat technology in arid region of Rajasthan. The results revealed that the total difference in productivity between modern and traditional technology was estimated to be about 62 per cent. The modern technology increased the production by 62.30 per cent over the traditional variety and the difference in varietal technology contributing nearly 46 per cent, while remaining 14 per cent was shared by complementary inputs. In present study, the farmers who are following backward integration are integrated farmers and rest of the farmers are non-integrated farmers. Mohan (2009) studied the impact of IPM technology in Haveri district, Karnataka. The results of decomposition analysis showed that total difference in output between IPM and non-IPM was 28.47 per cent in total and IPM technology component alone contributed 19.86 per cent.

Wide variation in yield levels in chilli resulting in fluctuation in prices and farmers are facing problems like high transportation cost, viral diseases, quality deterioration by contamination of pesticides, industrial chemicals and aflatoxins (Rao and Rao, 2014). It is vitally important to support the chilli farmers to produce high quality sustainable food safe spices to compete in the international market. So, the agribusiness firms are focussing on clean spice to gain the profits from international market by providing service backward integration with farmers. In this service farmers are also getting profits through gaining more output. The study is taken with was focused on following objective "to study the impact of backward integration on input use pattern and profitability of chilli farmers.".

\section{MATERIALS AND METHODS}

Multistage random sampling design was adopted for selection of sample at different levels viz., for selection of district, mandals and villages in the present study. Two major Agribusiness firms, i.e., ITC and Synthite that are following backward integration in chilli farming in Prakasam district were purposively selected for the study. In Andhra
Pradesh, Prakasam district was selected as the integrated chilli farmers of both ITC and Synthite are present in this district. Four mandals from of Prakasam district, viz., Naguluppala Padu, Tallur, Bestavaripeta and Recharla mandals were selected based on based on the maximum number of chilli farmers present. Naguluppala Padu and Tallur districts are selected based on maximum number of chilli farmers that are integrated with Synthite company. While in case of ITC, Bestavaripeta and Recharla mandals are having maximum number of integrated chilli farmers were selected. From each mandal two villages are selected. A total 8 villages are selected. From each village, 8 integrated farmers and 8 non-integrated farmers were selected. Total 128 farmers were selected for the study. The sample size was done by considering the population of farmers. The desired sample size was determined by using Cochran's (1963) formula below,

$$
n=\frac{n_{o}}{1+\frac{n_{o}-1}{N}}
$$

Where $n_{0}=\frac{z^{2} p q}{e^{2}}$

$n=$ Sample size

$N=$ Population size

$z=$ Confidence level

$p=$ Proportion of the population

$q=1-p$

$e=$ Allowable error

If the population is finite then the sample size error will be reduced slightly. This is because a given sample size provides proportionately more information for a finite population than for an infinite population. In that case, Cochran (1963) recommends ' $p$ ' to take the value of 0.5 in which case ' $n$ ' will be maximum and the sample will yield at least the desired precision. Sample size of integrated chilli farmers in each village becomes 8.3 $\sim 8$ that is 8 villages selected for the study for equal allocation of sample in the villages.

\section{Costs and Returns Calculation}

The structure of the average costs and returns of the integrated farmers and non-integrated chilli 
farmers were calculated. The costs and returns are calculated for rupees per hectare.

Variable Cost $=$ Value of human labour + Value of owned and hired machined power + Value of seeds purchased + Value of manures + Value of fertilizers + Value of plant protection chemicals + Irrigation + Interest on working capital

Fixed cost $=$ Depreciation, Repairs and Maintenance + Land Revenue, cess and taxes + Imputed rental value of owned land+ Interest on owned fixed capital etc.,

Total cost $=$ Variable costs + Fixed costs

Gross returns $=$ Yield ${ }^{*}$ Price

Gross margin $=$ Gross returns - Total variable costs

\section{Decomposition Analysis}

Chilli farming under backward integration system followed integrated management system for agricultural practices for better farming. In order to identify the effects of inputs impact on production of integrated and non-integrated chilli farmers, decomposition analysis was undertaken. It reveals the total productivity, profitability and input use pattern difference between integrated and nonintegrated chillies cultivation system.

The output decomposition model developed by Bisaliah (1977) was used for investigating the contribution of various constituent sources to the input use pattern, productivity and profitability difference between the integrated and nonintegrated farmers. For any two different production functions, the total change in the productivity can be brought out by shifts in the production parameters that defined the production functions itself and by the changes in the input-use levels. Therefore, the production function was considered as the convenient econometric model for decomposing the productivity difference.

$$
\begin{array}{r}
\ln \mathrm{Y}= \\
\ln \mathrm{b}_{0}+\mathrm{b}_{1} \ln \mathrm{X}_{1}+\mathrm{b}_{2} \ln \mathrm{X}_{2}+\mathrm{b}_{3} \ln \mathrm{X}_{3}+\mathrm{b}_{4} \ln \mathrm{X}_{4}+ \\
\mathrm{b}_{5} \ln \mathrm{X}_{5}+\mathrm{b}_{6} \ln \mathrm{X}_{6}+\mathrm{b}_{7} \ln \mathrm{X}_{7}+u i
\end{array}
$$

Where, $Y=$ Gross returns (₹/ha),

$$
\begin{aligned}
& X_{1}=\text { Seed }(₹ / \text { ha }), \\
& X_{2}=\text { Human labour (₹/ha), }
\end{aligned}
$$

$$
\begin{aligned}
& X_{3}=\text { Machine power }(₹ / h a), \\
& X_{4}=\text { Manures }(₹ / h a), \\
& X_{5}=\text { Fertilizers }(₹ / h a) \\
& X_{6}=\text { Plant protection chemicals }(₹ / h a), \\
& X_{7}=\text { Irrigation }(₹ / h a), \\
& b_{j}=\text { Regression coefficients }(j=0,1,2 \ldots, k)(k=7), \\
& U_{i}=\text { Error term, and }
\end{aligned}
$$

The output decomposition model used in this study was,

$$
\begin{aligned}
& \ln Y_{1}=\ln b_{01}+b_{11} \ln X_{11}+b_{21} \ln X_{21}+b_{31} \ln X_{31} \\
& \quad+b_{41} \ln X_{41}+b_{51} \ln X_{51}+b_{61} \ln X_{61}+b_{71} \\
& \quad \ln X_{71}+u_{i 1}
\end{aligned}
$$

$$
\begin{array}{r}
\ln Y_{2}=\ln b_{02}+b_{12} \ln X_{12}+b_{22} \ln X_{22}+b_{32} \ln X_{32}+b_{42} \\
\ln X_{42}+b_{52} \ln X_{52}+b_{62} \ln X_{62}+b_{72} \ln X_{72}+u_{i 2} \ldots
\end{array}
$$

Where, $Y, X_{1^{\prime}} X_{2^{\prime}} X_{3^{\prime}} X_{4^{\prime}} X_{5^{\prime}} X_{6^{\prime}} X_{7} b_{j}$ and $u_{i}$ are as denoted in Equation (1). However, Equations (2) and (3) represents integrated and non-integrated regression functions, respectively. The difference between the equations of integrated and nonintegrated farms is as given in equation (4) below:

$$
\begin{aligned}
\ln Y_{1} & -\ln Y_{2}=\ln \left(Y_{1} / Y_{2}\right)=\left\{\ln b_{01}-\ln b_{02}\right\}+\left\{\left(b_{11}-b_{12}\right)\right. \\
& \ln X_{12}+\left(b_{21}-b_{22}\right) \ln X_{22}+\left(b_{31}-b_{32}\right) \ln X_{32}+\left(b_{41}-\right. \\
& \left.b_{42}\right) \ln X_{42}+\left(b_{51}-b_{52}\right) \ln X_{52}+\left(b_{61}-b_{62}\right) \ln X_{62}+ \\
& \left.\left(b_{71}-b_{72}\right) \ln X_{72}\right\}+\left\{b_{11} \ln \left(X_{11} / X_{12}\right)+b_{21} \ln \left(X_{21} / X_{22}\right)\right. \\
& +b_{31} \ln \left(X_{31} / X_{32}\right)+b_{41} \ln \left(X_{41} / X_{42}\right)+b_{51} \ln \left(X_{51} / X_{52}\right)+ \\
& \left.b_{61} \ln \left(X_{61} / X_{62}\right)+b_{71} \ln \left(X_{71} / X_{72}\right)\right\}+u_{i 1}-u_{i 2}
\end{aligned}
$$

The decomposition Equation (4) gives an approximate measure of the percentage change in output in backward integration chilli farming system in the production process. The first flower bracketed expression on the right-hand side of equation (4) is the measure of percentage change in output due to shift in scale parameter of the production function. The second flower bracketed expression is the difference between output elasticities each weighted by natural logarithms of the volume of that input used under non-integrated farmer category, a measure of change in output is due to shift in the slope parameters of the production function. The third flower bracketed expression is the sum of the natural logarithms of the ratio of each 
input of integrated to non-integrated farmers, each weighted by the output elasticity of that input. This expression is a measure of change in the output due to change in per hectare quantities of inputs used in the production process.

\section{RESULTS}

The structure of the average costs and returns of the integrated farmers and non-integrated chilli farmers was presented in Table 1 . The average gross margin of the integrated chilli farmers was ₹ $1,78,631.53,78,631.53$ per ha while that of nonintegrated chilli farmers was ₹ $1,14,060.14$ per ha. This implies that the integrated chilli production was more profitable than non-integrated chilli production in the study area as the integrated chilli farmers are getting more per unit price than non-integrated farmers. Non-integrated chilli farmers were facing price uncertainty due to price fluctuations in the market price of chilli.

Table 1: Costs and returns of integrated and nonintegrated chilli farmers $(₹ / h a)$

\begin{tabular}{|c|c|c|}
\hline Variables & $\begin{array}{l}\text { Integrated } \\
\text { farming }(n=64)\end{array}$ & $\begin{array}{l}\text { Non-integrated } \\
\text { farming }(\mathrm{n}=64)\end{array}$ \\
\hline Seed & $20,258.13$ & $16,459.82$ \\
\hline Human labour & $82,390.00$ & $1,08,368.50$ \\
\hline Machine power & $23,009.53$ & $20,827.42$ \\
\hline Manures & $13,755.44$ & $9,289.53$ \\
\hline Fertilizers & $40,846.11$ & $37,002.70$ \\
\hline $\begin{array}{l}\text { Plant protection } \\
\text { chemicals }\end{array}$ & $44,121.80$ & $33,520.00$ \\
\hline Irrigation & $18,968.75$ & $10,115.63$ \\
\hline Miscellaneous expenses & $5,637.20$ & $3,531.60$ \\
\hline $\begin{array}{l}\text { Interest on working } \\
\text { capital }\end{array}$ & 5606.51 & 5364.66 \\
\hline $\begin{array}{l}\text { Total variable costs } \\
\text { (TVC) }\end{array}$ & $3,04,593.47$ & $2,91,479.86$ \\
\hline Depreciation & 360.41 & 290.38 \\
\hline Land revenue & 500 & 500 \\
\hline $\begin{array}{l}\text { Rental value of own } \\
\text { land }\end{array}$ & 43281.60 & 38471.95 \\
\hline Interest on fixed capital & 3224.85 & 1987.07 \\
\hline Total fixed cost (TFC) & $47,366.86$ & $44,249.40$ \\
\hline Total cost (TVC+TFC) & $3,51,960.33$ & $3,35,729.26$ \\
\hline Yield (Qtl/ha) & 51 & 45 \\
\hline Gross returns (GR) & $4,64,865$ & $4,05,540$ \\
\hline $\begin{array}{l}\text { Gross margin (GR- } \\
\text { TVC) }\end{array}$ & $1,78,631.53$ & $1,14,060.14$ \\
\hline
\end{tabular}

The seed cost per hectare of integrated farmers was ₹ 20,258.13 while for non-integrated farmers it was, ₹ 16,459.82. Integrated farmers are purchasing chilli fruit then they dry it to obtain seed so, quantity purchased was high. Whereas non-integrated farmers are purchasing direct seeds. Human labour cost per hectare for integrated farmers was ₹ $82,390.00$ while for non-integrated farmers it was $₹ 1,08,368$. The difference is due to the use of more human labour for spraying pesticides and application of fertilizers by non-integrated farmers than integrated farmers. The cost of machine power, manures and irrigation for integrated farmers were $₹ 23,009.53$, ₹ 13,755.44 and ₹ 18,968.75 respectively, and same for non-integrated farmers were ₹ $20,827.42$, ₹ 9,289.53 and ₹ 10,115.63 respectively. The cost of fertilizers and plant protection chemicals for integrated farmers were ₹ 40,846.11 and ₹ 44,121.80. The cost of fertilizers and plant protection chemicals for non-integrated farmers was ₹ $37,002.70$ and ₹ 33,520

The cost difference between integrated farmers and non-integrated farmers for fertilizers and plant protection chemicals is due to the purchase of costly pesticides by integrated farmers than nonintegrated chilli farmers. Fixed cost per hectare as estimated for integrated farmers was ₹ 47,367 and for non-integrated farmers was ₹ 44,249 . The input cost components of integrated and non-integrated farmers were depicted in Fig. 1.

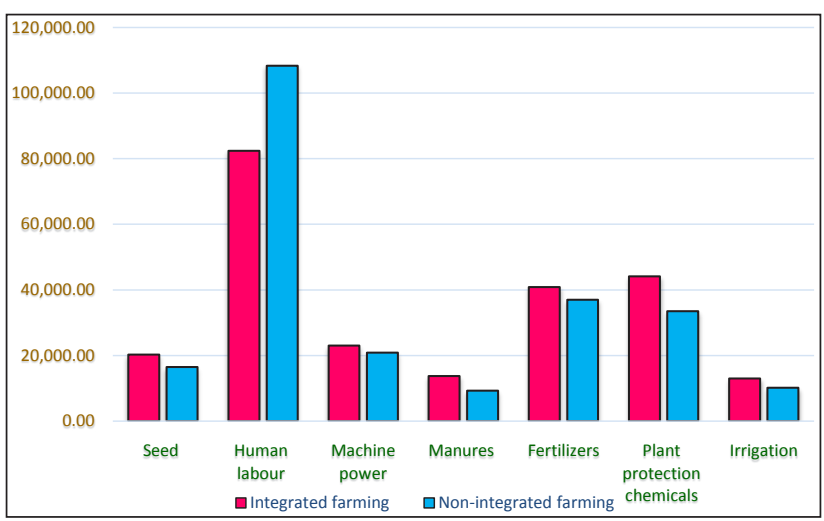

Fig.1: Input costs of integrated and non-integrated farmers

Decomposition analysis was used to estimate the contribution of various resources to the outcome difference between integrated and non-integrated farmers. The outcome difference resulted by adoption of backward integration technology between the integrated and non-integrated 
productions was decomposed into its constituent sources and results are presented in Table 2. The decomposition analysis showed that the per hectare returns of integrated farming was 13.28 per cent higher than that of non-integrated farming. The backward integration technology component was contributing 3.70 per cent to the total increase in output. This implies that with no further input application, chilli outcome could be increased by 3.70 per cent just by adopting the backward integration technology. Technical change affects the output by shifting either intercept or the slope coefficients, or both. Technical changes divided into neutral technical and non-neutral technical changes. This revealed a -940.03 per cent contribution in the scale parameter (i.e., Neutral technical change) and a 943.73 per cent contribution from the slope parameters (i.e., non-neutral technical change).

Table 2: Decomposition analysis

\begin{tabular}{|c|c|c|}
\hline S1. No. & Particulars & Percentage \\
\hline & \multicolumn{2}{|c|}{ Total observed difference in output 13.28} \\
\hline 1. & Source of output growth & \\
\hline (a) & Neutral component & -940.03 \\
\hline \multirow[t]{2}{*}{ (b) } & Non-neutral component & 943.73 \\
\hline & $\begin{array}{l}\text { Total estimated difference in output } \\
\text { due to technology }\end{array}$ & 3.70 \\
\hline 2. & Input contribution & \\
\hline (a) & Seeds & 1.37 \\
\hline (b) & Human labour & 12.06 \\
\hline (c) & Machine power & 0.17 \\
\hline (d) & Manures & -0.09 \\
\hline (e) & Fertilizers & -2.51 \\
\hline (f) & Plant protection chemicals & -0.96 \\
\hline \multirow[t]{2}{*}{ (g) } & Irrigation & 0.46 \\
\hline & $\begin{array}{l}\text { Total estimated difference in output } \\
\text { due to input difference }\end{array}$ & 9.58 \\
\hline
\end{tabular}

The total contribution of changes in the levels of input use to the outcome differences between the two groups was 9.58 per cent. This implies that the outcome of the integrated farming could increase by 9.58 per cent if the input use leads to increase in the same level as that of the non-integrated farming. Backward integration with agribusiness firms providing certain inputs and technical guidence to the farmers, which makes the farmers to produce more productively than non- integrated farmers. .The major contributor amongst all the inputs to the difference in returns was the cost incurred by the farmers for using of human labour $(12.06 \%)$ followed by seed $(1.37 \%)$. Machine power and irrigation are found to be positively contributing but at a lower level i.e., 0.17 per cent and 0.46 per cent respectively. This implies that the integrated farmers gained a higher outcome by spending more on seed, human labour, machine power and irrigation than the non-integrated farmers. Manures, fertilizers and plant protection chemicals were found to reduce the gross returns. This means that the costs of manures, fertilizers and plant protection chemicals adopted by the non-integrated farmers increased output by 0.09 per cent, 2.51 per cent and 0.96 per cent respectively. Divya (2014) reported that per acre returns of chilli contract farmers were 55.14 per cent higher than non-contract farmers, the major contribution for higher income was human labour $(8.20 \%)$, irrigation $(1.59 \%)$ and manures $(0.14 \%)$. Fertilizers $(-2.20 \%)$ and plant protection chemicals $(-1.80 \%)$ influencing negatively to the income of contract farmers. It could be suggested that usage of manures, fertilizers and plant protection chemicals on higher side leading to inefficiencies.

\section{CONCLUSIONS}

The decomposition analysis showed that the per hectare returns of integrated farming was 13.28 per cent higher than that of non-integrated farming. The integrated technology component was contributing 3.7 per cent to the total increase in output. The total contribution of changes in the levels of input use to the outcome differences between the two groups was 9.58 per cent. The major contributor amongst all the inputs to the difference in returns was the cost incurred by the farmers on human labour (12.05 per cent) followed by seed (1.36 per cent). Machine power and Irrigation found to be positively contributing but at a lower level i.e., 0.16 per cent and 0.45 per cent respectively. This implies that the integrated farmers gained a higher outcome by spending more on seed, human labour, machine power and irrigation than the non-integrated farmers. Manures, fertilizers and plant protection chemicals were found to reduce the gross returns. This means that the costs of manures, fertilizers and plant protection chemicals adopted by the non-integrated farmers increased output by 3.55 per cent.

The study revealed that farmers who are following 
backward integration are getting more outcome through technology and proper input usage. So, backward integration technology increases output and quality of the produce, so it should be expanded by an assured alternative agency (Government or co-operative) to increase quantity and value of export of chilli. Creating awareness on optimum use of inputs by Agricultural Department, can help the farmers in reducing the excess usage of fertilizers and plant protection chemicals.

\section{REFERENCES}

Bisaliah, S. 1977. Decomposition analysis of output change under new production technology in wheat farming some implications to returns on investment. Indian Journal of Agricultural Economics, 32: 193-201.

Cochran, W.G. 1963. Sampling Techniques. (2 ${ }^{\text {nd }}$ Ed.). New York: John Wiley and Sons.
Divya, K. 2014. Value chain analysis of Chillies in southern Tamil Nadu. M. Sc. (Ag.) Thesis. Tamil Nadu Agricultural University, Coimbatore.

Gawaria, K.M.,Gajja, B.L and Pathak, R. 2010. Decomposition analysis of output change under new wheat technology in arid region of Rajasthan: an econometric study. Annals of Arid Zone, 49(2): 131-136

Mohan, H.P. 2009. Impact of IPM technology on cotton and paddy production in Haveri district - an economic analysis. Ph.D (Ag.) Thesis. University of Agricultural Sciences, Dharwad.

Rao, V.C.S., and Rao, G.K. 2014. An insight into chilli cultivation and risk management procedures with special reference to Karnataka and Andhra Pradesh. International Journal of Business and Administration, 2: 144-155.

Sharma, D., Khatri, A. and Mathur, Y.B. 2014. Backward Integration of Supply Chain Management: A Case Study. International Journal of Emerging Technology and Advanced Engineering, 4(5): 867-868. 